\title{
Do Muslim Women Need Saving?
}

\author{
Lila Abu-Lughod \\ Cambridge and London: Harvard University Press, 2013. 326 pages.
}

In this extension of her important 2002 article in American Anthropologist, Lila Abu-Lughod examines the problematic nature of the western discourse surrounding Muslim women. In particular, she is interested in how western political programs in countries like Iraq and Afghanistan use the status of girls and women to validate their claims to occupy, colonize, or otherwise meddle in Muslim countries' internal affairs. Abu-Lughod shows how the human rights discourse surrounding grim situations (often aggravated or caused by western interventions and other maneuverings) relies on a kind of one-downtrodden-Muslim-female-fits-all scenario. This book analyzes the "idea of the Muslim woman," a character often in need of western liberation, and argues that the lives of Muslims are more complicated and nuanced than the popular media would have us believe.

Abu-Lughod begins her Introduction by reflecting on her fieldwork as an anthropologist in Egypt, an experience that taught her a great deal about the lives of Muslim women and has influenced her view that there is a "disjuncture between my experiences and these public attitudes" (p. 4). In other words, what the West thinks about Muslim women - their hopes, dreams, aspirations, and experiences - is radically different than what Muslim women actually experience. These fantasies, much like the fantasies about Muslim men as irrational and hopelessly violent, "rationalize American and European international adventures across the Middle East and South Asia" (p. 7). Muslim women are represented as lacking agency, a result in part of the alignment of sexual freedoms with personal liberation, about which Wendy Brown has written. AbuLughod sets off on her project to deconstruct and analyze the intersection among feminism, human rights language, and politics with the hope that the actual complicated, diverse, and multifaceted lives of Muslim women can contribute to a critical reflection on the growing movement for women's rights.

In chapter 1, the author sets her sights on Afghanistan, a state well known for its violence and poverty, not to mention the mass suffering of the general population. As she skillfully points out, the plight of Afghan girls and women serves a foundational role in arguments for American intervention. While the Taliban certainly deserve the demonization they have received in the press, so do the numerous other factions that target women as well as religious minorities and ethnic groups like the Hazara. As she reminds us, some of these groups are in "the U.S. backed government" (p. 29). 
The media firestorm that accompanied the American invasion and occupation relied on common tropes, including the veil, which served as the symbol of the Taliban, Islam, and a wide array of subjects all blurred together ( $\mathrm{p}$. 32). Through her analysis, Abu-Lughod argues that "we need to work against the reductive interpretation of veiling as the quintessential sign of women's unfreedom, even if we object to the state imposition of this form, as in Iran or with the Taliban" (p. 40). The veil's position as the dominant symbol of Muslim women's suffering obfuscates the very serious challenges these women face - and who would place removing the veil last in a long list of grievances, coming after ending warfare, improving security, and providing education and access to basic health services.

While Islam, through a patriarchal reading, may contribute to the problems Afghan women face, their situations are exacerbated by the consequences of a war economy, which has created poverty, violence, and a myriad of abuses stemming from unending warfare. As one example, young girls are sold off to old men in "distress sales" or "sent away to save them from roving bands of Taliban youth" (p. 52). These are not the result of religion or culture - they are reactions to a dangerous situation in which Muslim women have limited options.

Chapter 2 examines some of the popular literature that claims to address concerns surrounding the lives of Muslim girls and women. In Nicholas Kristof's Half the Sky (co-authored with Sheryl WuDunn), the only white women to appear are white saviors, individuals who give up their time or careers to help abused brown and black girls and women. As Abu-Lughod points out: "The only American men who appear are those like Kristof himself, who rescues prostitutes from brothels, or those, like the late dean of Columbia University's School of Public Health, who devote themselves to fighting maternal mortality" (p. 62). Ayaan Hirsi Ali's work presents a very different approach, one that holds Islam solely responsible for abuses and crimes against Muslim women regardless of circumstance. Abu-Lughod describes the mythical place where all these women live as "IslamLand," an oppressive space that is contrasted with the West's liberation, freedom, and safety.

In chapters 3 and 4, she examines how pulp nonfiction stories of Muslim women in captivity, abusive marriages, and other terrible situations help to sustain western fantasies about the Orient. In these stories, the United States and Europe are presented as the standard by which all others are compared. The genre is characterized by "coercion and lack of consent, absence of choice, and unfreedom," sold into sexual slavery or forced into an arranged marriage, kidnapped, held against their will, and usually sexually assaulted, often at the hands of male relatives (p. 91). 
These stories offer titillation and are frequently pornographic in their details of sexual violence, and thus constructed to reinforce Orientalist fantasies about violent Muslim men and their victims. As Abu-Lughod points out, certain words and phrases are used to frame these stories, such as "violent Muslim," "nightmare," "forced," "sex slave," and "survival" (p. 99). This genre of pornography is "tied to a racial politics and a legacy of colonial or racial domination" that represents IslamLand with a whole series of tropes about non-whites ranging from religious fanaticism to sexual deviancy (p. 103). In several cases, these stories have proven to be total fiction or exaggerations of actual events.

However, they serve an important purpose: They substantiate western claims of superiority and validate colonial and imperial interference in the affairs of Muslim countries. She argues:

Self-righteous horror about the barbarism of "the other" is married to voyeuristic titillation, along the way facilitating the personalization of such powerful symbols of liberalism as freedom and choice. The freedom that honor crimes books like this celebrate and that the scandalizing of honor crimes affirms turns out to be the freedom to have sex and leave home. (p. 123)

This presentation does several things. It assumes that Muslim unions cannot be sexually healthy; distracts us from the violence within western societies; and also avoids the role that colonialism, imperialism, and the modern state play in violence against women.

Chapter 5, an exploration of "women's rights" in Muslim countries, presents a critical and complicated system of competing desires, goals, and outcomes that involve religion, culture, politics, class, economics, and family relationships. According to her analysis, the lives of women in Muslim-majority countries is not just a matter of Islam, which plays one of many roles in a complicated social system that can offer both negative and positive outcomes. This chapter's two case studies, Egypt and Palestine, represent a myriad of ways in which women's lives are impacted by governments and NGOs, whose notions of rights may be diametrically opposed, suggesting how "dependent the operation of Muslim women's rights is on the larger political situation" (p. 171).

In chapter 6, Abu-Lughod returns to her original concern of linking women's rights to political intervention, specifically in Afghanistan. Here, she reflects upon her work as an anthropologist conducting fieldwork in Egyptian communities. In reflecting on the women in these communities, she examines several women's rights organizations - Sisters in Islam, Women Living under Islamic Laws (WLUML), Musawah, and Women's Shura Council - to argue that many "circuits" participate in women's rights work in Muslim countries. 
To understand how this works, one must ask two foundational questions: "What are the competing authorities involved in regulating or influencing the lives of Muslim women?" and "What are the channels women use to gain rights?" In some cases, religious institutions serve a positive role, offering educational and professional opportunities. Problems like domestic violence, which Abu-Lughod discusses at length, are not simply a matter of "religion" or "tradition," but involve economics, family dynamics, and personal issues like depression and anger management. There is a "range of global and class inequities" that impact women's lives, and they are not all rooted in Islamic institutions or ideologies (p. 200).

In the Conclusion, Abu-Lughod argues that far from a clash of civilizations, of East vs. West, women's lives are determined by competing choices often rooted in complex family dynamics. Islamic feminists offer something the West cannot - a language familiar to the larger communities in which these women through which rights can be argued. In both the Qur'an and Sunnah we have examples of a liberative Islam, of gender equality, women's rights, and the importance of education. While we share a common humanity, this is a "humanity subjected to different forces and expressed in different registers" (p. 227). Iliff School of Theology, Denver, CO 